\title{
Effect of Gully Headcut Treatment on Sediment Load and Gully Expansion in the Sub Humid Ethiopian Highlands
}

\author{
Assefa D. Zegeye ${ }^{1, *}$, Tammo S. Steenhuis ${ }^{2,3}$, Wolde Mekuria ${ }^{4}$, Dessalegn C. Dagnaw ${ }^{3}$, Meseret B. Addisse ${ }^{3}$, \\ Seifu A. Tilahun ${ }^{3}$, Tadele A. Kasse ${ }^{1}$ \\ ${ }^{1}$ Amhara Region Agricultural Research Institute, Ethiopia \\ ${ }^{2}$ Biological and Environmental Engineering, Cornell University, USA \\ ${ }^{3}$ School of Civil and Water Resources Engineering, Institute of Technology, Bahir Dar University, Ethiopia \\ ${ }^{4}$ International Water Management Institute (IWMI), Ethiopia
}

Copyright $\subset 2017$ by authors, all rights reserved. Authors agree that this article remains permanently open access under the terms of the Creative Commons Attribution License 4.0 International License

\begin{abstract}
The Ethiopian government has been implementing a land restoration program that aimed to restore degraded ecosystems and double agricultural productivity throughout the country since 2010 . However, the success of the restoration program has been limited due to the lack of integrating gully erosion control measures. Consequently, many reservoirs in Ethiopia and downstream riparian countries have lost their storage capacity due to sedimentation, and studies demonstrated that gully erosion is one of the degradation hotspots within watersheds and contribute considerable proportion of the total sediment loads from a particular watershed. This study was conducted in one of large gullies in the Debre-Mawi watershed, northwestern Ethiopia to quantify the effect of gully head treatment in reducing the amount of sediment load generated from uplands and from the gully itself. We measured discharge, and sediment load and concentration in 2013 and 2014 at the upstream (inlet) and downstream ends (outlet) of the studied gully. Before the 2014 rainy phase, a gully headcut was stabilized with gabions at the bed and the gully bank was regarded to $45^{\circ}$. The gully head retreated 12 $\mathrm{m}$ in 2013 but gully head retreat was stopped following the implementation of the treatment in 2014. The total sediment load and sediment concentration at the outlet was reduced by $42 \%$ and $30 \%$ respectively, in 2014 (i.e., after treatment) when compared to 2013 (i.e., before treatment). The result of this study support that controlling the upward retreat of gully head is effective in reducing sediment load and concentration as well as upward movement and expansion of gullies. However, maintenance of gully head control measures is the key to sustain the benefits.
\end{abstract}

Keywords Bank Erosion, East Africa, Lake-Tana, Sediment, Soil and Water Conservation

\section{Introduction}

Soil and water conservation have been implemented in
Ethiopian highlands since 1970s under the umbrella of the World Food Program 'Food for Work' [1]. However, this practice has only been sustainable as long as the program was actively engaged. One of the reasons was that farmers (the main stakeholders) were not involved in planning and evaluation of the benefit of soil and water conservation (SWC) measures and their indigenous experience and knowledge were rarely included [1]. This generally has resulted in failure of the SWC programs to bring desired results and a voluntary adoption of SWC technologies by farmers over the last four decades.

Gully erosion is one of the most damaging forms of soil erosion. In the Ethiopian highlands, gullies are particularly severe covering large tracts of areas and silting up rivers and reservoirs [2-4]. Extensive areas of agricultural lands are affected each year leading to irreversible changes in soil productivity and affecting the food security [5]. Most gullies in Ethiopia have been advancing uphill. Previous research confirmed that the upward head migration was the most important factor in gully expansion and sediment production $[6,7]$.

Controlling gully erosion is more difficult and expensive than sheet and rill erosion. Once formed, it requires a huge investment to rehabilitate. It also requires knowledge of the actual gully development processes in the targeted area. This is because any gully rehabilitation practices that do not try to deal with the actual gully formation mechanics, including lack of maintenance of the installed erosion control structures are inefficient $[7,8]$. The Ethiopian landscape is a living example (Figure 1). Failed structures can be found in almost every gully where gully treatments were attempted. Trees planted on the bank immediately collapse in to gullies. For example, a diversion structure applied in the Debre Mawi watershed that aimed at rehabilitating formed a new gully (Figure 1c and d) following the diversion [7]. Thus, understanding patterns of gully and gully-complex development in Ethiopian highlands and its mitigation mechanisms, is of paramount importance not only from a scientific perspective, but especially to enable land managers 
to develop sustainable planning strategies. Moreover, quantitative information is rarely available on the effectiveness of gully headcut treatment techniques. The objective of this study is therefore, to quantify the effect of gully head protective measures on reducing sediment load, sediment concentration and headcut retreat rate. To do this, we selected a large gully in the Debre Mawi watershed which was previously studied by Tebebu et al. (2010).

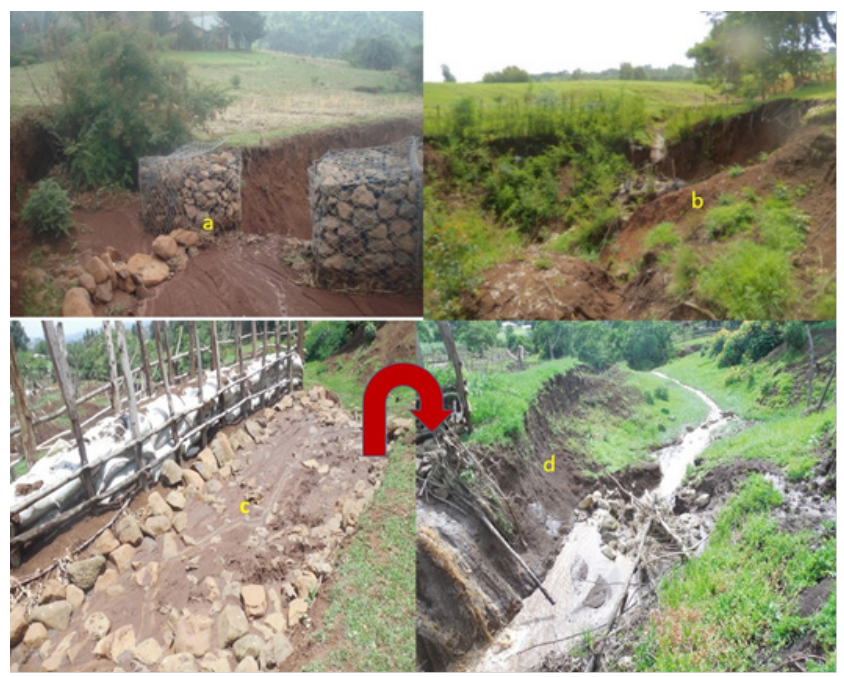

Figure 1. Challenges of gully rehabilitation, (a) inappropriate plantation of check dams forcing a preferential flow direction, (b) After the gully bank is regraded and planted, the bank slipped due to scouring undercut, (c and d), the diverted flow initiated a new gully in the Debre Mawi watershed (2013)

\section{Material and Methods}

\subsection{Study Area Description}

This study was conducted in the Debre Mawi watershed, located about $30 \mathrm{~km}$ south of Lake Tana at $11^{\circ} 20^{\prime} 13^{\prime \prime} \mathrm{N}$ and $37^{\circ} 25^{\prime} 55^{\prime} \mathrm{E}$. The watershed drains an area of $608 \mathrm{ha}$, and its elevation ranges from 2186 to $2366 \mathrm{~m}$ above sea level. The slope in the watershed ranges from 1 to $2 \%$ for flat bottom lands and from 8 to $30 \%$ elsewhere. Rainfall is unimodal and the mean annual rainfall is about $1240 \mathrm{~mm}$. More than $70 \%$ of the annual rainfall occurs during June, July, and August. The average monthly temperature is $20^{\circ} \mathrm{C}$.

About $92 \%$ of the watershed is cultivated. The remaining portion of the watershed consists of communal grazing areas $(6 \%)$, shrubs and eucalyptus woodlots $(2 \%)$. The dominant soil types are Nitisol, Vertisols, and Regosol [9]. Nitisols dominate the upper parts of the watershed and is highly suitable for crop production. Vertisols are found in the lower portion of the watershed where crops such as tef (Eragrostis tef), chickpea (Cicer arietinum), and grass pea (Lathyrus sativus) are cultivated. Regosols occurs on the steep hillslopes and highly eroded parts of the watershed.

While the watershed is located at the most productive area of the country, the land is being devastated by expanding gully networks (Figure 1) and to a lesser degree by sheet and rill erosion on the cultivated slopes $[6,9,10]$. The gully networks are mostly found in the periodically saturated bottomlands. One of the possible reasons for the saturation could be that lava dykes in the watershed affect the hydrology, forcing subsurface flow to the surface and causing saturated source areas for surface runoff upslope [3, $7,11]$.

\subsection{Data Collection}

\subsubsection{Measurements of Gully Expansion and Soil Loss}

A $389 \mathrm{~m}$ gully (Figure 2c) for which some information was available from an earlier study [3] was selected. The mean channel slope was 0.03 . The gully was divided into 35 cross sections with the distance between two successive cross-sections varying between 6 and $13 \mathrm{~m}$ depending mainly on the uniformity of the gully width. This helps to minimize errors during calculating the average cross-sectional area between two cross sections.

Three gully topographic surveys were conducted: (1) before the rainy phase on 28 June 2013, (2) after the rainy phase on 18 Sep 2013 (Figure 2), and (3) after the rainy phase on 18 Oct 2014 to quantify the extent of gully expansion and determine temporal changes in gully dimension. The gully cross-sectional geometry was surveyed by dividing the cross section into trapezoidal segments at abrupt changes in the ground profile, and measuring the width and depth of the gully at each segment. Cross-sectional area (A) and Volume (V) were then calculated:

$$
\begin{array}{r}
A=\frac{1}{2} \sum_{i=1}^{n-1}\left|\left(w_{i} h_{i+1}-w_{i+1} h_{i}\right)\right| \\
V=\sum_{j=1}^{N-1} L_{j}\left(\frac{A_{j}+A_{j+1}}{2}\right)
\end{array}
$$

where $n$ is the number of trapezoidal segment sides of height $\mathrm{h}$ and located a distance $w$ from the left gully edge in a cross section (Figure 2c), $i$ is a trapezoidal segment index, $W$ is cross section width, $\mathrm{j}$ is cross section index, $\mathrm{N}$ is number of cross sections, and $L_{j}$ is length of the gully section between cross sections $\mathrm{j}$ and $\mathrm{j}+1$.

The total soil loss volume over the monitoring period was then obtained by the difference in $V$ after and before the 2013 and 2014 rainy phases. To convert the volume of soil loss (obtained from gully topographic measurements) to mass, four soil bulk density (BD) samples were collected from four soil layers of the sidewalls of the gully $2 \mathrm{~m}$ downstream from the headcut with a $98 \mathrm{~cm}^{3}$ cylindrical core sampler.

To evaluate the effects of headcut treatment on sediment load and concentration, two rectangular weirs, one at the upper end (inlet) and the other at the lower end (outlet) of the gully were installed prior to the rainy season of 2013. During rainfall-runoff events, stage height, and stream velocity were measured and sediment samples were collected at 10-minute intervals at both weirs from the beginning of the storm until base level was reached or flow stopped. Sediment samples were collected in one-liter bottles at two-thirds of the depth of the stream starting at the initial 
rise of the hydrograph until the initial depth was reached again. Stage height was measured manually by tape measure and the runoff velocity in the stream was measured by timing a float, put in at a distance $5 \mathrm{~m}$ upstream of the weir. The weirs followed the contour of the bank and did not restrict the flow, so that over or underestimation due to the cross-sectional change is minimal. In addition, during days without rainfall (or only base flow), discharge and sediment measurements were made and samples were collected three times daily (morning, noon, and evening) at the two weirs.

The discharge was determined in two different ways: (1) by multiplying the wetted cross-sectional area above the weir by two-thirds of the surface velocity; and (2) through rating curve for the occasions that the velocity is not available. Sediment concentrations were determined by filtering the samples over pre-weighed filter papers in the laboratory, which were then oven-dried for 24 hours at $105^{\circ} \mathrm{C}$ and reweighed to the nearest $0.01 \mathrm{~g}$. The suspended sediment load $(\mathrm{Y})$ was then calculated using the equation $Y$ $=Q C$ where $Q$ is discharge and $C$ is sediment concentration. Total amounts of runoff and suspended sediment per event were then obtained by integrating the individual measurements over time.

\subsubsection{Headcut Treatment}

We conducted three consecutive group discussions with the members of the local community and agricultural experts to identify a particular gully for the implementation gully head treatment (Figure 3a). In addition, the members of the local community were involved in the implementation and evaluation of gully head treatments. Accordingly we selected one $5 \mathrm{~m}$ high headcut and implemented the intervention with the support from the local community. The local community participated in collecting local materials such as stones woods and excavating equipment, while the researcher provided materials such as gabion and sacks.

The selected gully headcut and the sidewalls near the headcut was regraded to $45^{\circ}$ to decrease the slope and hence the bank failure (Figure 3b). Plant species [13] such as elephant grass (Pennisetum purpureum) and Sesbania susban were planted on the regraded banks (Figure 3b). In addition, to dissipate the flowing energy, one gabion check-dam underneath the headcut and others consecutive check-dams made of woods, at short distances below the headcut, were installed prior to the 2014 rainy season (Figure $3 b)$.

\section{Results and Discussion}

\subsection{Estimation of Gully Erosion by Measuring the Changes in Gully Dimension}

The total length of the gully between the two weirs was
$389 \mathrm{~m}$ and the length from the headcut to its outlet in 2014 was $309 \mathrm{~m}$ with average depth $4.6 \mathrm{~m}$ and width $26 \mathrm{~m}$. Its surface area was $9580 \mathrm{~m}^{2}$ in 2013 and $9960 \mathrm{~m}^{2}$ in 2014. The combined change in volume obtained from manual measurements of gully geometry between 2013 and 2014 was $4463 \mathrm{~m}^{3}$. The measured bulk density for this gully was $1.22 \mathrm{~g} \mathrm{~cm}^{-3}$. Hence the total soil loss from the gully during the 2013-2014 was 5445 ton or $160 \mathrm{tha}^{-1} \mathrm{yr}^{-1}$.

\subsection{Soil Loss as Affected by Gully Head Treatment}

Runoff and suspended sediment were measured at the inlet and outlet weirs during 34 storms in 2013 and 31storms in 2014 rain phases. The discharge at the outlet (excluding the base flow) in 2013 was $81 \mathrm{~mm}$, while it was $74 \mathrm{~mm}$ in 2014 . The total sediment passing the inlet during the storm flow was $151 \mathrm{t}$ in 2013 and $61 \mathrm{t}$ in 2014. The sediment loss during the rainstorms (excluding the base flow) at outlet was $1236 \mathrm{t}$ in 2013 and $764 \mathrm{t}$ in 2014 (Table 1). The daily sediment concentration and sediment load in 2014 were decreased by $33 \%$ and $40 \%$, respectively (Table 1). During base flow, $7 \mathrm{t}$ of soil entered the gully and $573 \mathrm{t}$ was transported out of the gully (Table 1a). Thus, in the 2013 rain phase, the total sediment load entering the gully was $158 \mathrm{t}$ and leaving the gully was 1,809 t. During the 2014 rain phase, after the gully headcut was arrested, the storm-generated sediment load at the inlet was a total load of $61 \mathrm{t}$ and at the outlet was $764 \mathrm{t}$. During base flow, $14 \mathrm{t}$ and $284 \mathrm{t}$ of sediment loads were measured at the inlet and outlet, respectively. Thus, total sediment loads of $75 \mathrm{t}$ at the inlet and $1,048 \mathrm{t}$ at the outlet of the gully were measured during the 2014 monsoon season (Table 1).

The gully enrichment ratio for storm-generated sediment load in 2013 was 7.2 and it was 11.5 in 2014 (Table 1b) which means, about $92 \%$ of the suspended sediment load originated from the gully (Table 1, Figures $4 \& 5$ ). Including the base flow, over $90 \%$ of the sediment passing the outlet originated from the gully or the amount of sediment transported out of the gully was 10 to 14 times greater than at the inlet (Table 1b). In 2014, sediment concentration at the outlet of the gully slightly decreased towards the end of the rainy phase (similar to the inlet weir), whereas it increased during the 2013 rainy phase (Figure 5).

The sediment concentration at the downstream end (outlet) of the gully is significantly greater than at the upstream end (inlet) as clearly viewed in Figure 4 . The two pictures (inlet and outlet flow) in Figure 4 were taken at the same instance (August 6, 2014) and the outlet discharge color is dense brown indicating high sediment concentration whereas the inlet flow is light brown indicating a lower concentration. Quantitatively, this difference amounted to a high contribution to total sediment where more than $90 \%$ of the sediment originated from the gully itself (Table 1). 

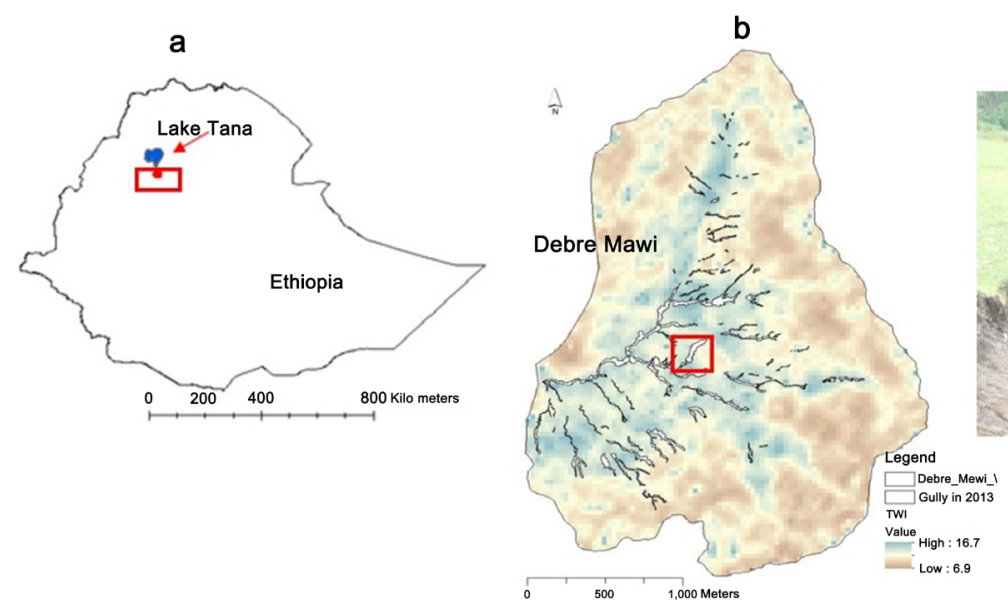

\section{C}

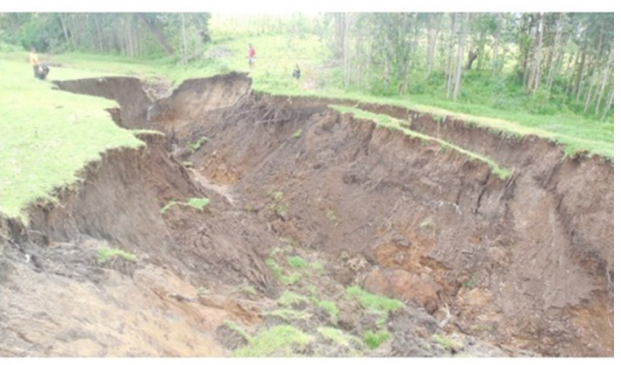

Figure 2. The relationship between gully formation locations and topographic wetness index (TWI), and gully expansion rate in 2013 in the Debre Mawi watershed (b), Ethiopia (a). Lines represent gully edges digitized from aerial imagery. (c) The picture taken in 2013 located around the center of the watershed marked with red rectangle in (b) was intended for gully head treatment in 2014.
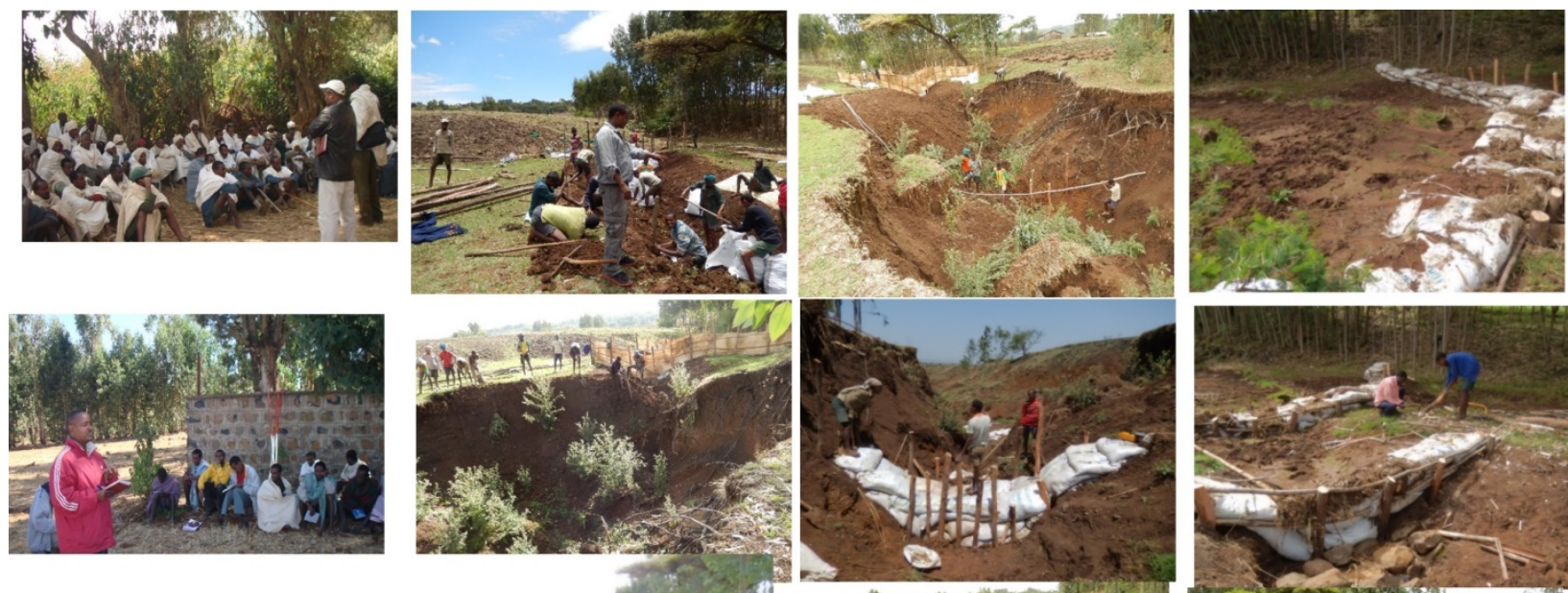

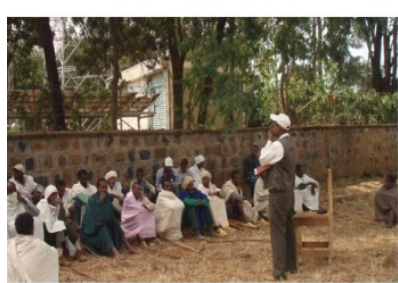

a

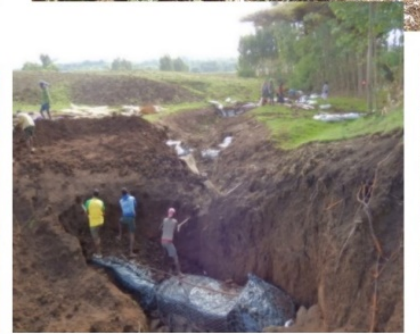

$\mathrm{b}$

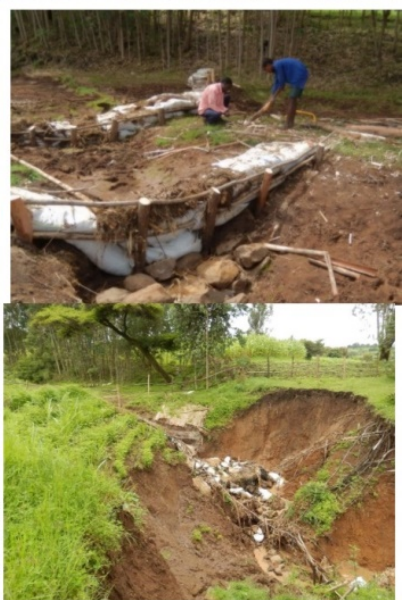

C

Figure 3. Gully headcut treatment started in May 2014, in the Debre-Mawi watershed. Pictures under group (a) show frequent discussions and trainings made by the researcher and watershed community to reach a consensus that gully can be protected and rehabilitated and to work together, (b) gully head treatment procedures, and (c) shows the success and challenge of gully treatment 


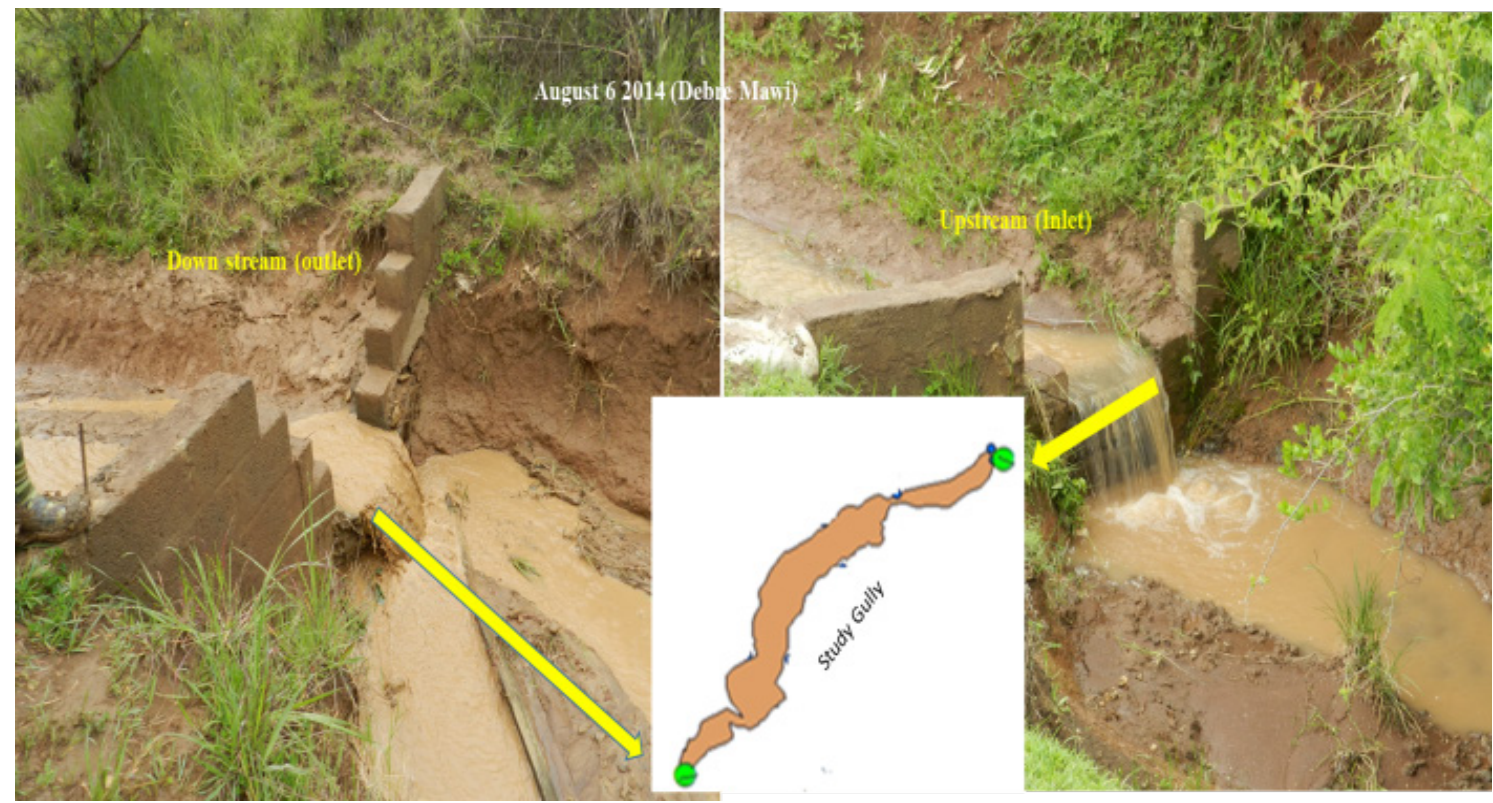

Figure 4. The visual sediment concentration comparison of the inlet and outlet discharge of the study gully, August 6, 2014

Table 1a. The Runoff, sediment load (SL), and average suspended sediment concentration (SSC) for both storm and base flows at the inlet and outlet of the gully for 2013 and 2014 .

\begin{tabular}{|c|c|c|c|c|c|c|c|c|c|c|}
\hline \multirow[b]{2}{*}{ Year } & & \multicolumn{3}{|c|}{ Storm flow } & \multicolumn{3}{|c|}{ Base flow } & \multicolumn{3}{|c|}{ Total } \\
\hline & & $\begin{array}{c}\text { Runoff } \\
\left(\mathrm{m}^{3}\right)\end{array}$ & $\begin{array}{c}\mathrm{SSC} \\
\left(\mathrm{g} \mathrm{L}^{-1}\right)\end{array}$ & $\begin{array}{l}\text { SL } \\
\text { (t) }\end{array}$ & $\begin{array}{c}\text { Runoff } \\
\left(\mathrm{m}^{3}\right)\end{array}$ & $\begin{array}{c}\mathrm{SSC} \\
\left(\mathrm{g} \mathrm{L}^{-1}\right)\end{array}$ & $\begin{array}{l}\text { SL } \\
(\mathrm{t})\end{array}$ & $\begin{array}{c}\text { Runoff } \\
\left(\mathrm{m}^{3}\right)\end{array}$ & $\begin{array}{c}\mathrm{SSC} \\
\left(\mathrm{g} \mathrm{L}^{-1}\right)\end{array}$ & $\begin{array}{l}\text { SL } \\
\text { (t) }\end{array}$ \\
\hline \multirow{2}{*}{2013} & Inlet & 8136 & 18.6 & 151 & 13673 & 0.5 & 7 & 21809 & 7.2 & 158 \\
\hline & Outlet & 14058 & 87.9 & 1236 & 23074 & 24.8 & 573 & 37132 & 48.7 & 1809 \\
\hline \multirow{2}{*}{2014} & Inlet & 8748 & 7.0 & 61 & 10526 & 1.3 & 14 & 19274 & 3.9 & 75 \\
\hline & Outlet & 12896 & 59.2 & 764 & 18014 & 15.8 & 284 & 30910 & 33.9 & 1048 \\
\hline
\end{tabular}

Table 1b. The Enrichment ratio, and the ratio of Sediment load (SL) from outlet relative to inlet of the gully for 2013 and 2014 monsoon season.

\begin{tabular}{ccccccccccc}
\hline Year & Types of ratio & Runoff & SSC & SL & Runoff & SSC & SL & Runoff & SSC & SL \\
\hline \multirow{2}{*}{2013} & Enrichment ratio & 0.7 & 3.7 & 7.2 & 0.7 & 47 & 81 & 0.7 & 5.7 & 10 \\
& The ratio of SL from gully & 0.42 & 0.79 & 0.88 & 0.41 & 0.98 & 0.99 & 0.41 & 85 & 0.91 \\
\multirow{2}{*}{2014} & Enrichment ratio & 0.5 & 7.5 & 11.5 & 0.7 & 10.9 & 19.3 & 0.6 & 7.7 & 13.0 \\
& The ratio of SL from gully & 0.32 & 0.88 & 0.92 & 0.42 & 0.92 & 0.95 & 0.38 & 89 & 0.93 \\
\hline
\end{tabular}




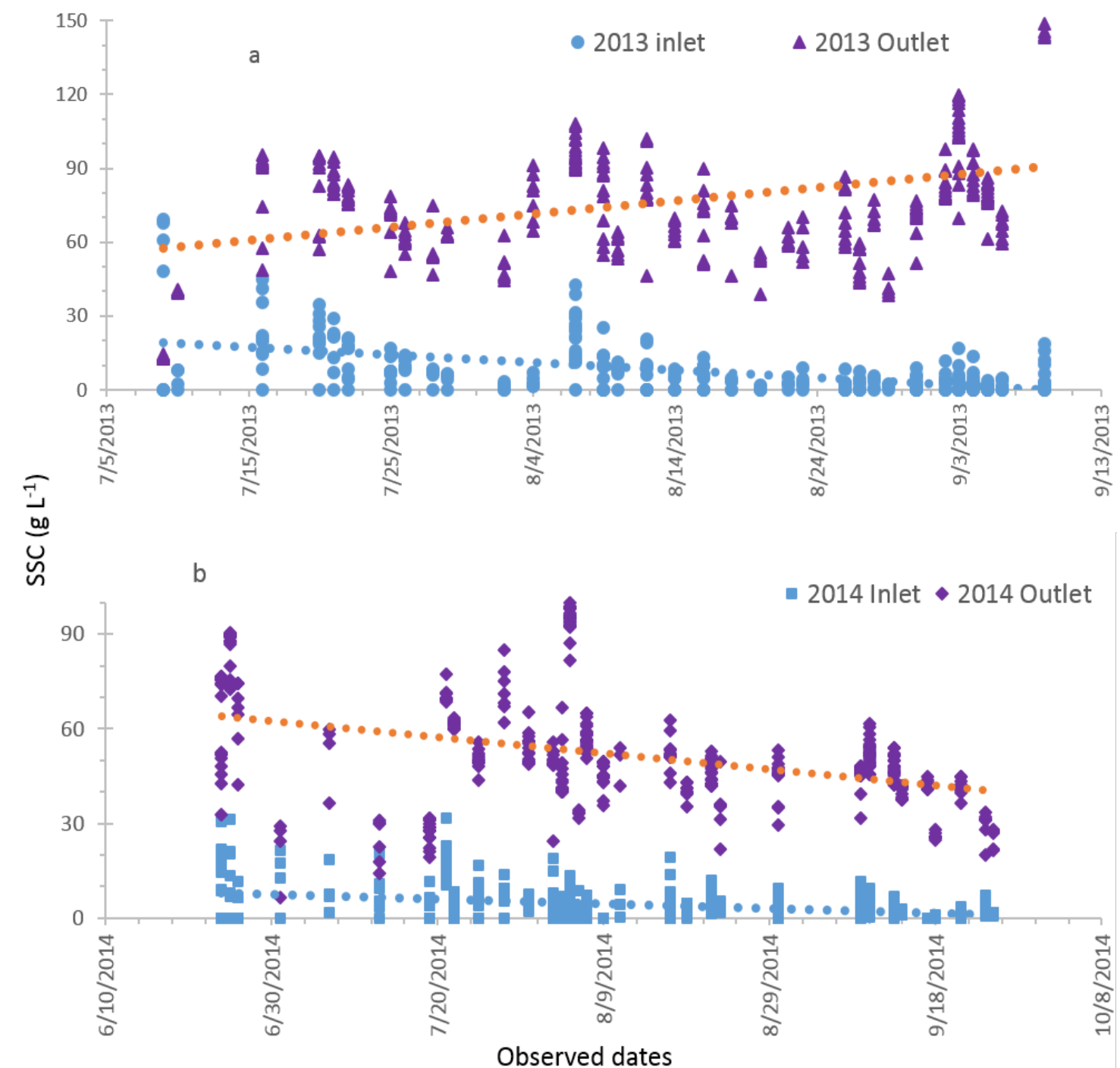

Figure 5. Comparison of sediment concentration at the inlet and outlet weirs as a function of time in 2013 and 2014. The top in each plot at a \& $b$ belongs to sediment concentrations at the outlet and the bottom in $\mathrm{a} \& \mathrm{~b}$ are concentrations at inlet.

\subsection{Effectiveness of Gully Head Treatment}

The gully headcut treatment started prior to 2014 rain phase (May, 2014) as shown in Figure 3. This treatment was successful in controlling the uphill migration of the headcut as compared to other untreated gullies in the watershed. The sediment load and sediment concentration were respectively reduced by $40 \%$ and $30 \%$ in 2014 as compared to 2013 . This is attributed to the implementation of gully headcut treatment in 2014 (Table 1, Figure 5). This was supported by the reduced upward migration of gully head following the implementation of the treatment. For example, in 2013, the headcut was linearly retreated by $12 \mathrm{~m}$ uphill whereas in 2014, the headcut was not retreated although there was a cross sectional growth or sidewall erosion (Figure 3c). Moreover, the rainfall in 2013 and 2014 was 917 and 1107 $\mathrm{mm}$ respectively, which is quite similar and this also support our argument that gully head treatment is effective in reducing sediment concentration and load.

However, the left sidewall of the headcut that was not regraded effectively was eroded by $1.5 \mathrm{~m}$ laterally (Figure $3 c$ ). In addition, almost all the wooden check dams installed below the gabion check dam were totally damaged and carried away by a single high flooding event $(90 \mathrm{~mm})$. On the right side of the treated gully, the planted vegetation (elephant grass and sesbania) started slumping as shown in the last photo of Figure 3c. This shows that in the (sub) humid Ethiopia highlands, where the soil saturates periodically, halting gully erosion is more difficult and expensive. Thus, designing measures to treat deep gullies in cost effective ways in a humid monsoon highland should be a priority in future research in order to reduce sediment loads in rivers. These consist of lowering water table elevation and regrading of the gully head and sidewall effectively. We also suggest, treating gullies at the start of their initiation and development to reduce costs of reclamation and reclaim gullies effectively. Further, research is required to evaluate the effectiveness of integrated (physical and biological measures) gully head treatment in reducing upward migration of gully heads. 


\section{Conclusions}

The results supported that gully headcut treatment is effective in reducing the upward migration of gully heads, and sediment concentration and load. We also observed that unless the gully control structures are maintained, they doomed to fail. This study is a good indicator of what areas need to be targeted to reduce sediment loads and thereby reduce damages on water resources infrastructures such as irrigation and hydropower dams. The result demonstrated that stabilizing big gullies is costly and difficult to manage. Thus, we suggest that gullies should be treated at the start of initiation and development.

\section{Acknowledgements}

This research was supported financially by the International Foundation for Science (IFS), Cornell University and Ministry of water, Irrigation and Energy, Ethiopia.

\section{REFERENCES}

[1] K. Herweg and E. Ludi. The performance of selected soil and water conservation measures - case studies from Ethiopia and Eritrea. Catena. 36(1): pp. 99-114, 1999.

[2] S. Daba, W. Rieger and P. Strauss. Assessment of gully erosion in eastern Ethiopia using photogrammetric techniques. Catena. 50(2): pp. 273-291, 2003.

[3] T. Tebebu, A. Abiy, H. Dahlke, Z. Easton, A. Zegeye, S. Tilahun, A. Collick, S. Kidnau, S. Moges and F. Dadgari. Surface and subsurface flow effect on permanent gully formation and upland erosion near Lake Tana in the northern highlands of Ethiopia. Hydrology and Earth System Sciences Discussions. 7(4): pp. 5235-5265, 2010.

[4] N. Haregeweyn, J. Poesen, G. Verstraeten, G. Govers, J. Vente, J. Nyssen, J. Deckers and J. Moeyersons. Assessing the performance of a spatially distributed soil erosion and sediment delivery model (WATEM/SEDEM) in Northern Ethiopia. Land Degradation \& Development. 24(2): pp. 188-204, 2013.
[5] B. Sonneveld and M. Keyzer. Land under pressure: soil conservation concerns and opportunities for Ethiopia. Land Degradation \& Development. 14(1): pp. 5-23, 2003.

[6] E. Langendoen, T. Tebebu, T. Steenhuis and S. Tilahun. "Assessing gully widening and its control in the Debra-Mawi watershed, northern Ethiopia". in Proceedings Conference on Science and Technology towards the Development of East Africa (ICST 2013), eds N. Gabbiye, E. Kaba, KK Monocha Singh, and S. Sharma (Bahir Dar University Institute of Technology: Ethiopia). 2013.

[7] A. Zegeye, S. Damtew, A. Tilahun, E. Langendoen, D. Dagnew, C. Guzman, T. Tebeby and T. Steenhuis. "Gully development processes in the Ethiopian Highlands". in 2nd International Conference on the Advancements of Science and Technology, eds B. Bantyirga, M. Mehari, VS Rao, BL Manocha, KK Singh, S. Geremew, and E. Tadesse (Bahir Dar: Bahir Dar Institute of Technology). 2014.

[8] E. Langendoen, A. Zegeye, T. Tebebu, T. Steenhuis, G. Ayele, $\mathrm{S}$. Tilahun and E. Ayana. Using computer models to design gully erosion control structures for humid northern Ethiopia. ICHE 2014, Hamburg-Lehfeldt \& Kopmann (eds)-Bundesanstalt für Wasserbau. 2014.

[9] T. Amare, A.D. Zegeye, B. Yitaferu, T.S. Steenhuis, H. Hurni and G. Zeleke. Combined effect of soil bund with biological soil and water conservation measures in the northwestern Ethiopian highlands. Ecohydrology \& Hydrobiology. 14(3): pp. 192-199, 2014.

[10] A.D. Zegeye, T.S. Steenhuis, R.W. Blake, S. Kidnau, A.S. Collick and F. Dadgari. Assessment of soil erosion processes and farmer perception of land conservation in Debre Mewi watershed near Lake Tana, Ethiopia. Ecohydrology \& Hydrobiology. 10(2): pp. 297-306, 2010.

[11] A.Z. Abiy, Geological controls in the formations and expansions of Gullies over hillslope hydrological processes in the highlands of Ethiopia, Northern Blue Nile Region, 2009, Cornell University.

[12] A.D. Zegeye, E.J. Langendoen, C.R. Stoof, S.A. Tilahun, D.C. Dagnew, F.A. Zimale, C.D. Guzman, B. Yitaferu and T.S. Steenhuis. Morphological dynamics of gully systems in the sub-humid Ethiopian Highlands: The Debre Mawi watershed. Soil. 2: pp. 443-458, 2016.

[13] G. Gyssels and J. Poesen. The importance of plant root characteristics in controlling concentrated flow erosion rates. Earth Surface Processes and Landforms. 28(4): pp. 371-384, 2003. 